\title{
An overview of structurally diversified anticonvulsant agents
}

FAISAL AL-OTAIBI

Department of Clinical Pharmacy

College of Pharmacy, Shaqra

University, Al-dawadmi

P. O. BOX 33, Saudi Arabia

Accepted December 15, 2018

Published online January 7, 2019

\begin{abstract}
There are several limited approaches to treat epilepsy in hospitals, for example, using medicines, surgery, electrical stimulation and dietary interventions. Despite the availability of all these new and old approaches, seizure is particularly difficult to manage. The quest for new antiepileptic molecules with more specificity and less CNS toxicity continues for medicinal chemists until a new and ideal drug arrives. This review covers new antiseizure molecules of different chemical classes, the exact mode of action of which is still unidentified. Newer agents include sulfonamides, thiadiazoles, semi- and thiosemicarbazones, pyrrolidine-2,5-diones, imidazoles, benzothiazoles and amino acid derivatives. These new chemical entities can be useful for the design and development of forthcoming antiseizure agents.
\end{abstract}

Keywords: antiepileptic agents, sulfonamides, imidazoles, thiadiazoles, benzothiazoles and amino acid derivatives

\section{INTRODUCTION}

Epilepsy is a collective term for a group of chronic CNS disorders. All kinds of epilepsies display the occurrence of unprovoked, excessive, sudden, self-regulated neuronal discharge that results in a seizure. Because of excessive neuronal discharge, the finely organized pattern of the integrative activity of the brain is abolished (1).

Prevalence of the disease is observed in every corner of the world, with underdeveloped countries being more vulnerable. It is estimated that almost 50 million people around the world are affected by epilepsy (2). Older people are more prone to epileptic spell (3). The exact etiology of the disease is still unknown. However, factors associated with epilepsy include brain trauma, strokes, brain cancer and drug and alcohol misuse, among others. The multifactorial origin of the disease produces a high degree of disablement to successful discovery of antiepileptic drugs (4). In many cases, there is no direct family relation to the epileptic condition at all. However, some researchers have confirmed that some special types of epilepsy take place more often in some families. It was recently revealed that such

\footnotetext{
*Correspondence, e-mail: f.alotaibi@hotmail.com
} 
types of epilepsy were connected with the transfer of specific genes from one generation to another (5-10). There are many mutated genes responsible for various types of inheritable epilepsies, for example, familial nocturnal frontal lobe epilepsy is caused by inheritance of mutated CHRNA2, CHRNA4 and CHRNB2 genes. In the same way, febrile seizures, generalized epilepsy with febrile seizures plus and Dravet syndrome are caused by inheritance of mutated SCN1A, SCN2A, SCN2B and GABRG2 genes. Many studies have confirmed that epigenetically facilitated regulation of $\mathrm{Na}^{+}$channel genes (SCN1A, SCN1B, SCN2A and SCN3A) associated with generalized epilepsy with febrile seizures plus (GEFS+) are mediated via DNA methylation and methyl-CpG-binding domain 2 (MBD2) binding (11). Some antiepileptic drugs produce epigenetic changes. For example, valproate induces defects of epigenetic transcriptional regulatory mechanisms in glial cells, resulting in reduced cell proliferation, which may in turn lead to cognitive dysfunction or mental illness $(12,13)$.

Over the past ten years, a large number of new antiepileptic drugs (AEDs) and nonpharmacologic remedies have been added to treat epilepsy. The new drugs are designed to address specific pathophysiologic defects such as seizure generation or spread where the old medicines are not useful any more. Other novel approaches to control epilepsy include electrical stimulation devices, such as vagus nerve stimulator (14-16), deep brain stimulation (DBS) $(17,18)$ and dietary interventions (ketogenic diet) (19-22). Despite the availability of all new and old AEDs, along with the arrival of new techniques, seizures are particularly challenging to treat. The old generation antiepileptic drugs (AEDs) such as phenobarbital, primidone, phenytoin, carbamazepine, ethosuximide and benzodiazepine are potent and extensively used but exhibit considerable adverse effects and also fail to adequately control seizures (23). On the other hand, new AEDs, for example gabapentin, topiramate, lamotrigine, levetiracetam, vigabatrin, and rufinamide are not as potent as the old AEDs and are used as an add-on therapy. They all exhibit significant CNS-related and other side effects (24). This study suggests that only a small number of new AEDs adequately manage major types of epilepsy, the remaining drugs control only one or two types. The undesired side effects and failure to control the major types of epilepsy compel the researchers to find candidates that would meet all the requirements for an ideal drug.

The antiseizure drugs, which are currently prescribed in the clinics, are categorized based on their mode of action as follows (Fig. 1):

(i) drugs that block the sodium channel, for example, phenytoin, carbamazepine, oxcarbazepine, etc.,

(ii) drugs that activate GABA-mediated inhibitory action, such as benzodiazepines, barbiturates, vigabatrin, tiagabine,

(iii) drugs that block the $\mathrm{Ca}^{2+}$ channel, for example, pregabalin, gabapentine, etc.,

(iv) drugs that inhibit glutamate receptors (both NMDA and AMPA), for example, felbamate, topiramate, etc.

Some drugs possess a combination of actions, often coupled with additional and unknown mechanisms $(25,26)$; these include valproic acid, lamotrigine, zonisamide, etc.

The newly designed and synthesized antiepileptic agents have been surveyed over the last few years. The diversity of chemical structures and various modes of action of anticonvulsant agents make it hard to attain a universal way of discovering new drugs. 


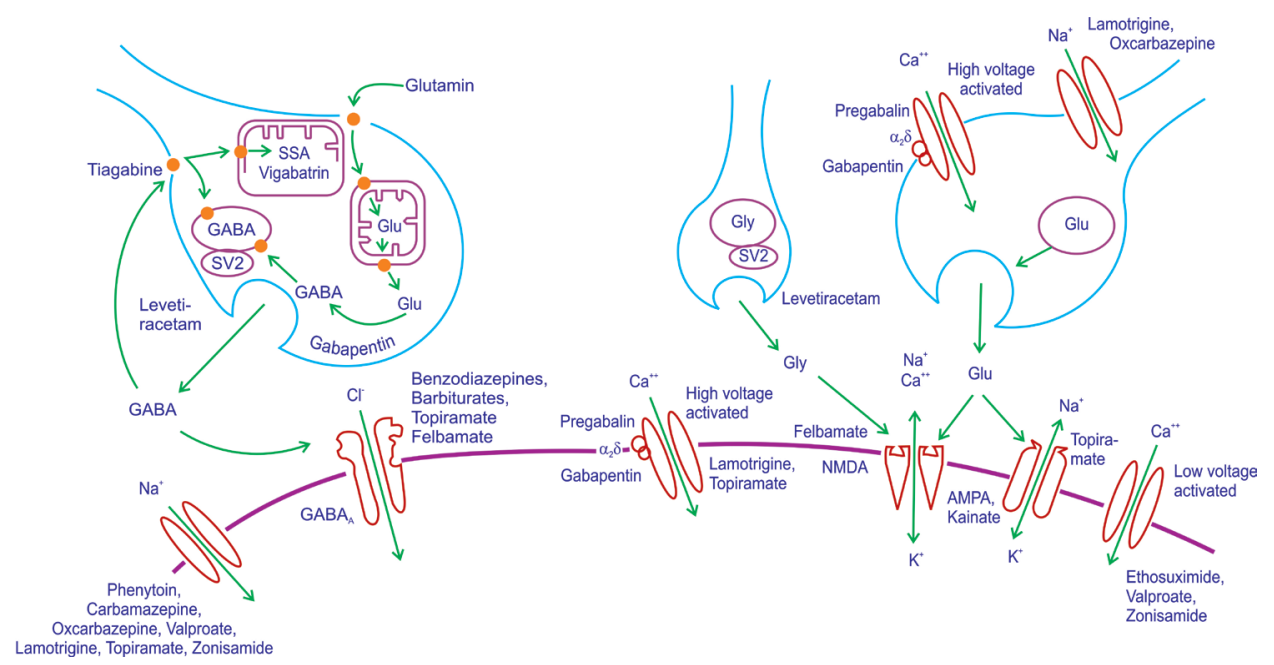

Fig. 1. Mechanism of action of antiepileptic drugs $\left(\alpha_{2} \delta\right.$ - auxiliary subunit of voltage dependent $\mathrm{Ca}^{2+}$ channels, AMPA - $\alpha$-amino-3-hydroxy-5-methyl-4-isoxazole propionic acid, GABA- $\gamma$-aminobutyric acid, Gly - glycine, Glu - glutamate, NMDA - N-methyl- $D$-aspartate, SSA - succinate semialdehyde, SV2 - synaptic protein 2).

Novel antiepileptic molecules are discovered via screening or modification in the structure of already existing drugs but not by a mechanism-based design.

This review highlights new antiseizure agents containing various chemical structures whose exact mode of action is unknown. These newly synthesized analogues comprise sulfonamides, heterocyclic compounds, functionalized amino acids, and others. These chemical classes of compounds can be useful for the design and development of new antiepileptic drugs in the future.

\section{NEW ANTICONVULSANT AGENTS: A STRUCTURE BASED REVIEW}

\section{Sulfonamide derivatives}

This class of drugs has displayed a large number of clinical uses. Some of these drugs are used as antimicrobials, also called sulpha drugs. Some are carbonic anhydrase (CA) inhibitors, which are used as diuretics and antiepileptic drugs. In search of newer anticonvulsant agents, researchers discovered acetazolamide and methazolamide (Fig. 2). In general, these drugs are 5-membered heterocycles containing a sulfonamide and an amide as well as a 1,3,4-thiadizole nucleus. They exhibit potent carbonic anhydrase inhibitory activity. Topiramate and zonisamide are recently developed antiepileptic drugs bearing different sulfonamide groups in their structure (Fig. 2). Scozzafava and Supuran (27-32) developed several new carbonic anhydrase inhibitors, which are mainly derivatives of sulfonamide. Recent progress in the development of anticonvulsant agents containing sulfonamide moiety is summarized in Table I. 
<smiles>CC(=O)Nc1nnc(S(N)(=O)=O)s1</smiles><smiles>CC1(C)O[C@H]2[C@@H](CO[C@]3(OOS(N)(=O)=O)OC(C)(C)O[C@H]23)O1</smiles><smiles>CC(=O)NC1SC(S(N)(=O)=O)=NN1C</smiles><smiles>COc1ccccc1CS(N)(=O)=O</smiles>

Fig. 2. Antiepileptic drugs containing a sulfonamide group.

\section{Derivatives of thiadiazole}

Thiadiazoles are five-membered heterocyclic rings bearing two nitrogen atoms and one sulfur with two nitrogen-carbon double bonds $(\mathrm{C}=\mathrm{N})$. These conjugated double bonds between atoms provide the thiadiazole ring aromatic property. Four likely structures can be perceived on the basis of the locations of one sulfur and two nitrogen atoms (Fig. 3). These structures do not interchange and are hence structural isomers (not tautomers). Various isomers of thiadiazole are used as the basic moiety in the process of drug discovery and development (36-38).<smiles>c1csnn1</smiles>

1,2,3-Thiadiazole<smiles>c1ncsn1</smiles>

1,2,4-Thiadiazole<smiles>c1cnsn1</smiles><smiles>c1nncs1</smiles>

1,2,5-Thiadiazole 1,3,4-Thiadiazole

Fig. 3. Four structural isomers of thiadiazoles.

Table II gives an overview of thiadizole-containing new derivatives that display significant antiseizure activity in various animal models.

\section{Semi- and thiosemi-carbazones as anticonvulsant agents}

During the last two decades, semicarbazones have been extensively investigated for their anticonvulsant properties (51-54). In the conventional screening process, 4-(4-fluorophenoxy) benzaldehyde semicarbazone was discovered as a lead molecule against the electroshock (MES) seizure test. The protective index of this compound is higher than that of carbamazepine, phenytoin and valproate (55). Later on, a large number of scholars have attempted to find new molecules with significant anticonvulsant activity (Table III). 
Table I. Recently designed and significantly active sulfonamide derivatives

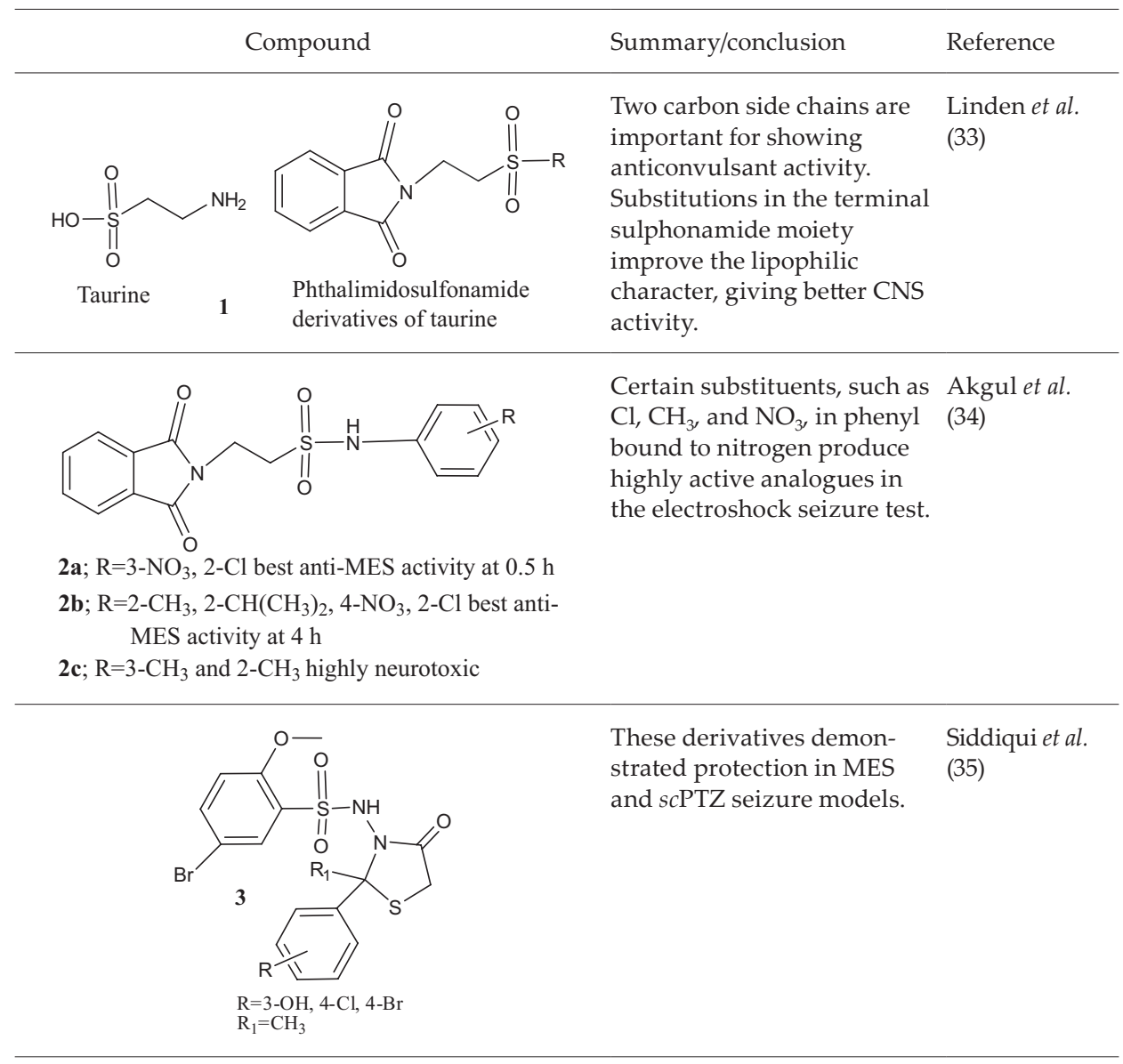

CNS - central nervous system, MES - maximal electroshock seizure, scPTZ - subcutaneous pentylenetetrazole

\section{Pyrrolidine-2,5-diones as anticonvulsants}

Derivatives of pyrrolidine-2,5-dione, as heterocyclic compounds, have been widely applied in medicinal chemistry. They exhibit abundant biological activities, especially in seizure and tyrosinase inhibitory action. Therefore, progress of new and efficient approaches for the preparation of multi-substituted pyrrolidine-2,5-dione derivatives is a burning issue in organic and medicinal chemistry (61).

Literature survey has revealed that Obniska and Kaminski (62-66), along with other researchers, worked extensively on pyrrolidin-2,5-diones as potential anticonvulsant agents. Some recently developed anticonvulsant agents having pyrrolidin-2,5-dione in their structure are presented in Table IV. 
Table II. Some recently developed thiadiazole derivatives as anticonvulsant agents

\begin{tabular}{lll}
\hline & Summary/conclusion & Reference \\
\hline $4 ; p-\mathrm{C}_{2} \mathrm{H}_{5}-\mathrm{O}_{-}-\mathrm{C}_{6} \mathrm{H}_{4}$ & $5 ; \mathrm{R}=$
\end{tabular}<smiles>c1cnc(NC2NSC(Nc3ncccn3)N2)nc1</smiles>

Derivative 6 was observed to Gupta et al. (40) be highly active in MES and scPTZ test models.<smiles>[R]c1ccc(/C=N/c2nnc([R17])s2)cc1</smiles>

7a; $2-\mathrm{Cl}, \mathrm{R}_{1}=\mathrm{H}$

$7 \mathbf{b} ; 4-\mathrm{Cl}, \mathrm{R}_{1}=\mathrm{H}$

8a; $2-\mathrm{Cl}, \mathrm{R}_{1}=\mathrm{CH}_{2}-\mathrm{C}_{6} \mathrm{H}_{5}$

$\mathbf{8 b} ; 4-\mathrm{Cl}, \mathrm{R}_{1}=\mathrm{CH}_{2}-\mathrm{C}_{6} \mathrm{H}_{5}$

9a; $2-\mathrm{Cl}, \mathrm{R}_{1}=\mathrm{CH}_{2}(4-\mathrm{Cl}) \mathrm{C}_{6} \mathrm{H}_{4}$

9b; 4-Cl, $\mathrm{R}_{1}=\mathrm{CH}_{2}(4-\mathrm{Cl}) \mathrm{C}_{6} \mathrm{H}_{4}$
These compounds displayed Ahmed et al. (41) moderate to good activity in the MES test.<smiles>[R]c1nnc(-n2c(/C=C/[Al])nc3ccccc3c2=O)s1</smiles>

These compounds exhibited Jatav et al. (42) excellent anti-MES and anti-scPTZ activity.

10a; $\mathrm{R}=\mathrm{C}_{6} \mathrm{H}_{5}, \mathrm{Ar}=4-\mathrm{Cl}-\mathrm{C}_{6} \mathrm{H}_{4}$

10b; $\mathrm{R}=3-\mathrm{Cl}-\mathrm{C}_{6} \mathrm{H}_{4}, \mathrm{Ar}=4-\mathrm{Cl}-\mathrm{C}_{6} \mathrm{H}_{4}$

10c; $\mathrm{R}=4-\mathrm{Cl}-\mathrm{C}_{6} \mathrm{H}_{4}, \mathrm{Ar}=$ pyridine<smiles>CCNc1nnc(-c2ccc(Cl)cc2Oc2ccccc2Cl)s1</smiles>

Compounds 11, 12 and 13 Foroumadi et al. (43) were the most active against both electroshock (MES) and chemoshock (PTZ) with an $E D_{50} 20.11$ to $35.33 \mathrm{mg} \mathrm{kg}^{-1}$. 


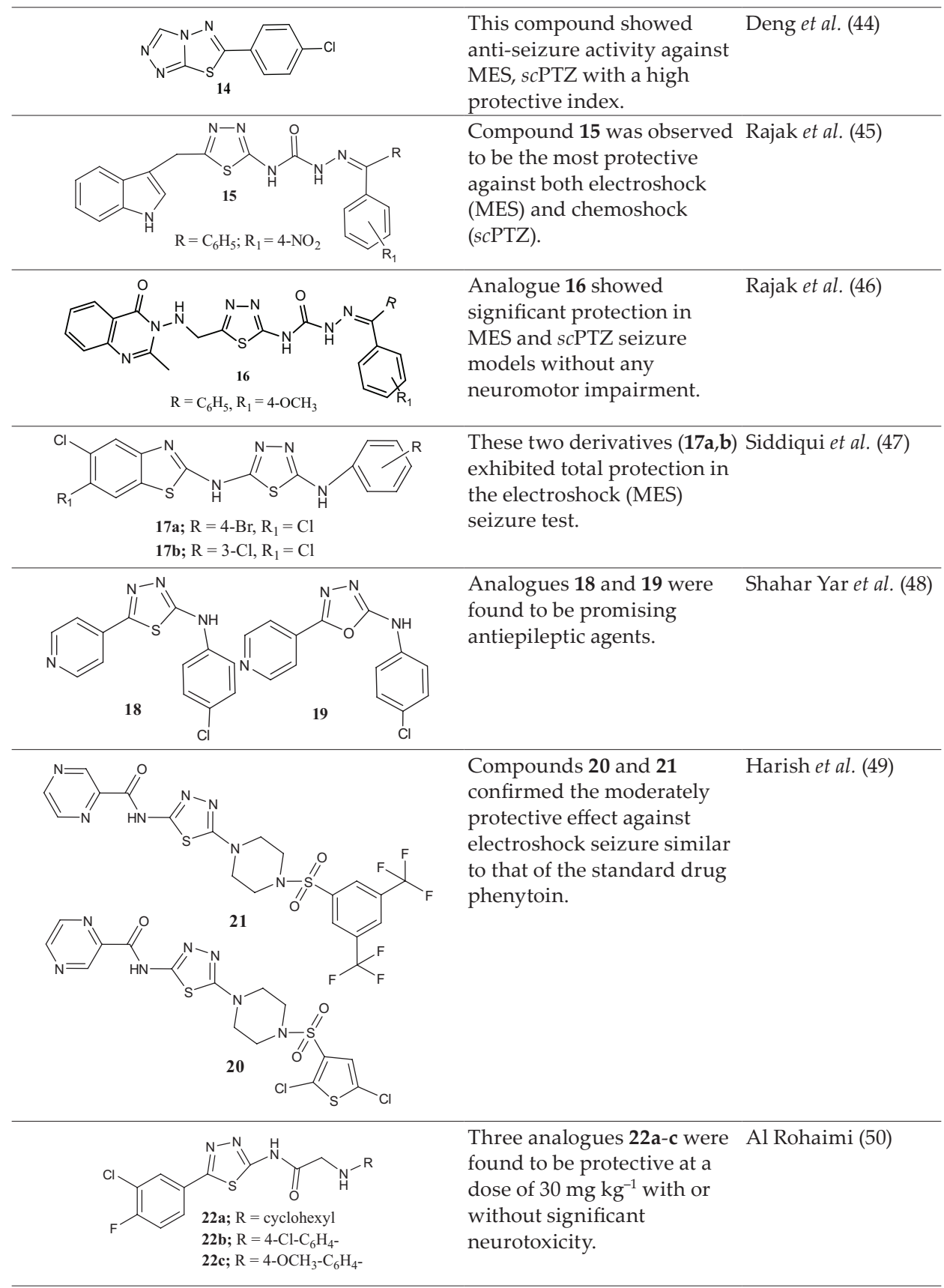

$E D_{50}$ - median effective dose, MES - maximal electroshock seizure, PTZ - pentylenetetrazole, scPTZ - subcutaneous pentylenetetrazole 
Table III. Some new semi- and thiosemi-carbazones as anticonvulsant agents

Summary/conclusion
Reference
highly active in the MES test
without any neuromotor
impairment.

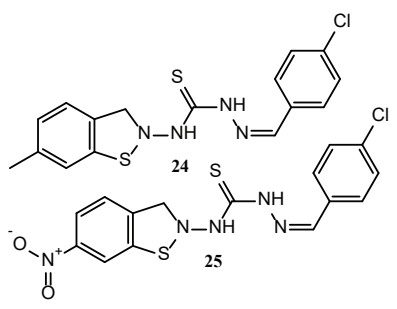

Analogues 24 and 25 showed promising outcomes against the MES seizure model with lesser or no neuromotor impairment.
Yogeeswari et al.

(57)<smiles>O=C1c2ccccc2C(=O)N1NC(=S)Nc1ccc(Cl)cc1</smiles>

Analogue $\mathbf{2 6}$ showed significant activity against MES, scPTZ and scSTY seizure tests without any neuromotor impairment
Yogeeswari et al.<smiles>[Y]C(=NNC([Y])Cn1ccnc1)Nc1ccccc1</smiles>

27a; $\mathrm{Ar}=$ naphthyl, $\mathrm{X}=\mathrm{S}, \mathrm{R}=3-\mathrm{Cl}$

27b; $\mathrm{Ar}=$ biphenyl, $\mathrm{X}=\mathrm{S}, \mathrm{R}=4-\mathrm{F}$ 27c; $\mathrm{Ar}=$ naphthyl, $\mathrm{X}=\mathrm{S}, \mathrm{R}=4-\mathrm{CH}_{3}$
All three derivatives were found to be highly active in the MES test.
Analogues 28a-c showed the highest degree of protection in

Azam et al. (60)<smiles>[R]c1ccc(/C=N/NC(=O)Nc2nc3c(ccc4ccccc43)s2)cc1</smiles>
MES and $s c$ PTZ seizure models.

MES - maximal electroshock seizure, scPTZ - subcutaneous pentylenetetrazole, scSTY - subcutaneous strychnine 
Table IV. Some newer pyrrolidine-2,5-dione as anticonvulsants

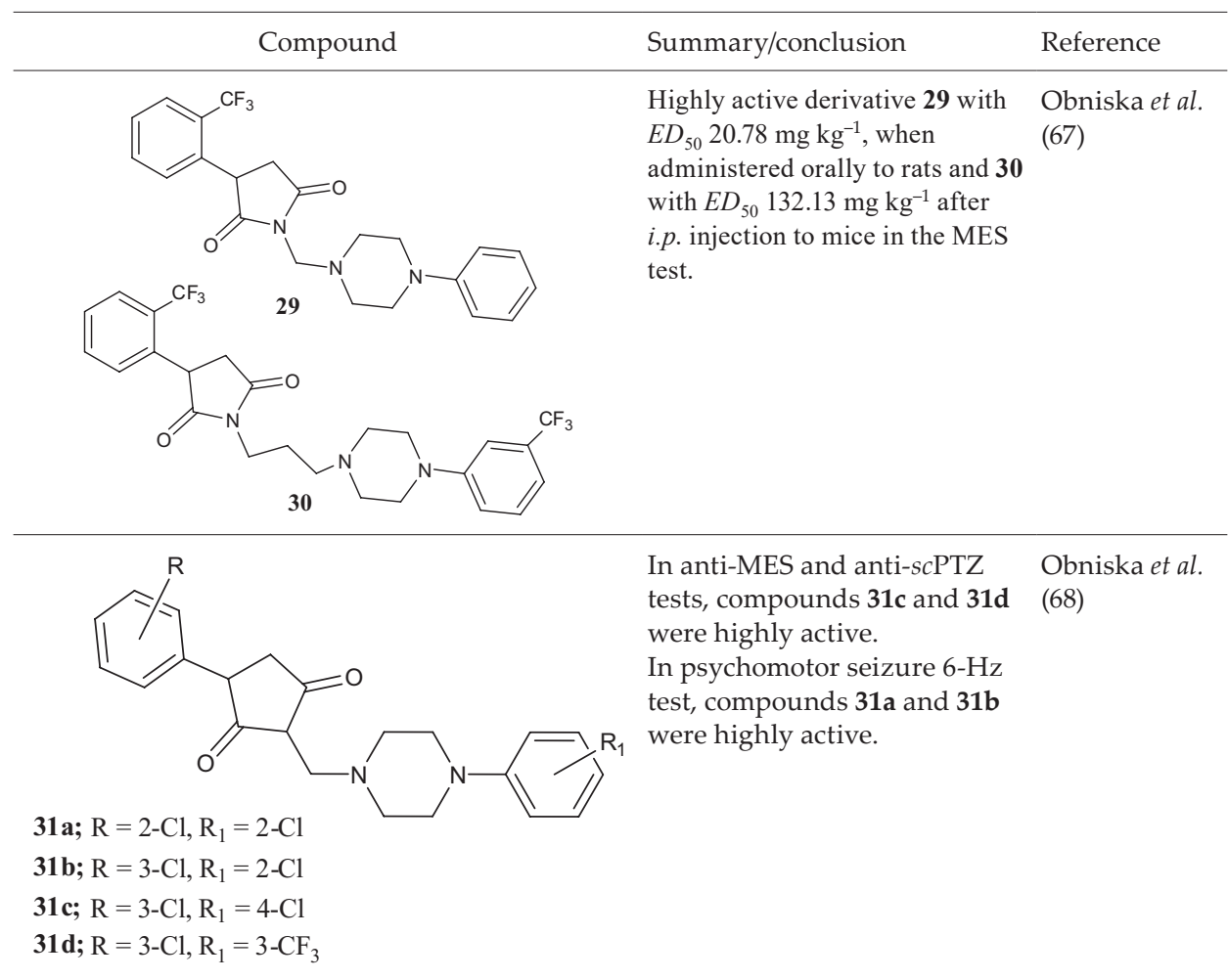

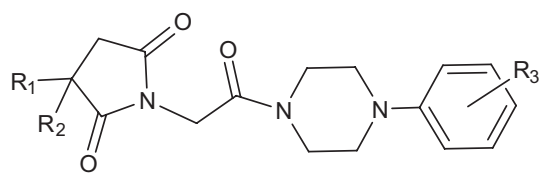

32a; $\mathrm{R}_{1}=\mathrm{H}, \mathrm{R}_{2}=\mathrm{H}, \mathrm{R}_{3}=3-\mathrm{CF}_{3}$

32b; $\mathrm{R}_{1}=\mathrm{CH}_{3}, \mathrm{R}_{2}=\mathrm{H}, \mathrm{R}_{3}=4-\mathrm{Cl}$

32c; $\mathrm{R}_{1}=\mathrm{CH}_{3}, \mathrm{R}_{2}=\mathrm{CH}_{3}, \mathrm{R}_{3}=4-\mathrm{Cl}$

32d; $\mathrm{R}_{1}=\mathrm{CH}_{3}, \mathrm{R}_{2}=\mathrm{CH}_{3}, \mathrm{R}_{3}=3-\mathrm{CF}_{3}$
Most anti-MES and anti-scPTZ Kamiński et al. compounds were $32 \mathrm{a}-\mathrm{d}$.

(69)

32a and 32c displayed high activity in the 6-Hz psychomotor seizure screening.<smiles>[R]N1CCN(CN2C(=O)CC([R])([R])C2=O)CC1</smiles>

Compounds 33a-c showed moderate to good activity in anti-MES and anti-scPTZ tests as well as 6-Hz psychomotor seizure screening.
Obniska et al.

(70)

33a; $\mathrm{R}_{1}=\mathrm{C}_{6} \mathrm{H}_{5}, \mathrm{R}_{2}=\mathrm{C}_{6} \mathrm{H}_{5}, \mathrm{R}_{3}=\mathrm{CH}_{2} \mathrm{CH}_{2} \mathrm{CH}_{2} \mathrm{OH}$

33b; $\mathrm{R}_{1}=\mathrm{C}_{6} \mathrm{H}_{5}, \mathrm{R}_{2}=\mathrm{CH}_{3}, \mathrm{R}_{3}=\mathrm{CH}_{2} \mathrm{CH}_{2} \mathrm{CH}_{2} \mathrm{OH}$

33c; $\mathrm{R}_{1}=\mathrm{C}_{6} \mathrm{H}_{5}, \mathrm{R}_{2}=\mathrm{CH}_{3}, \mathrm{R}_{3}=\mathrm{CH}_{3}$ 


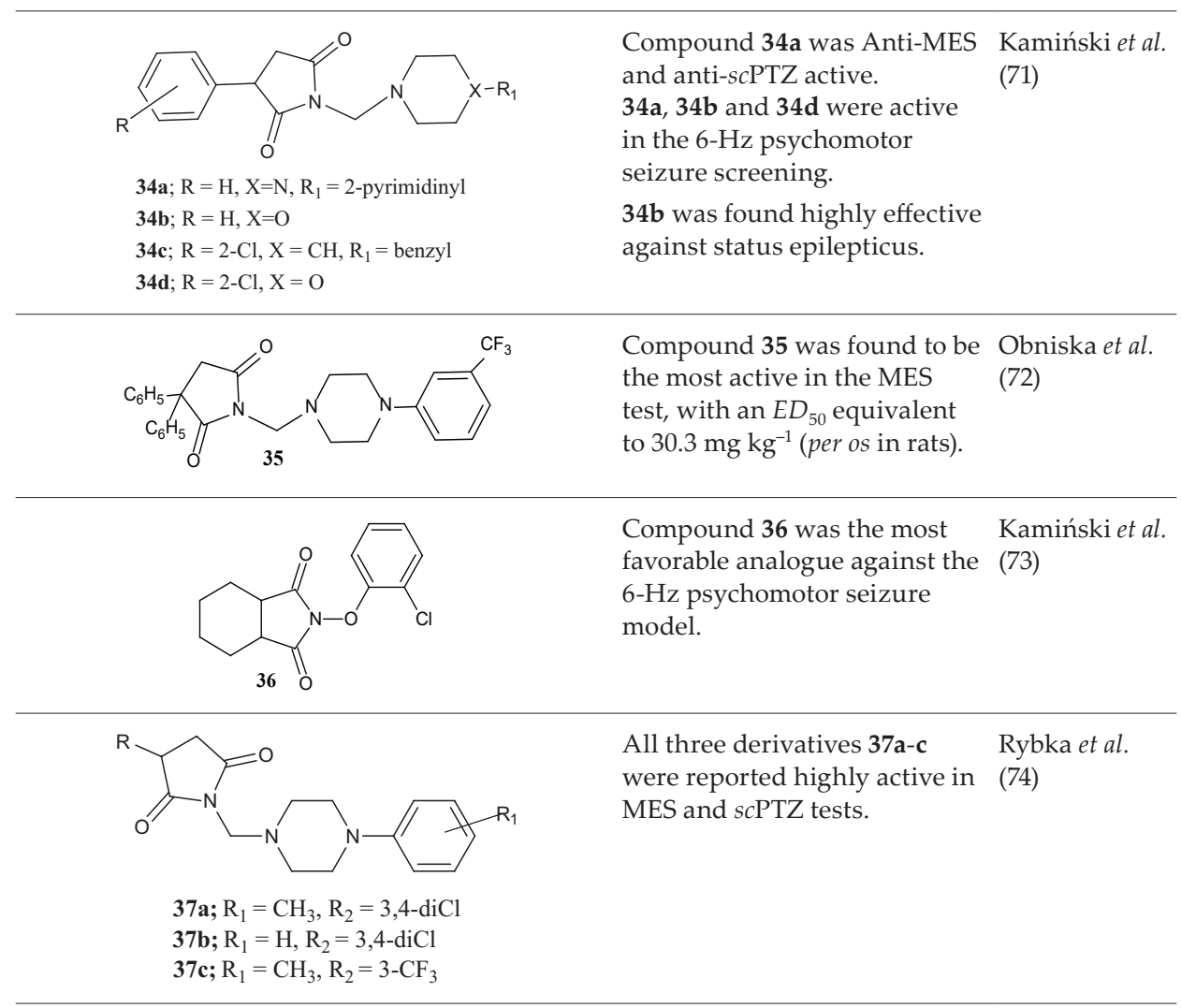

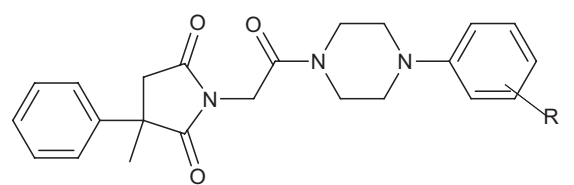

38a; $\mathrm{R}=\mathrm{H}, \mathbf{3 8 b} ; \mathrm{R}=2-\mathrm{F}, \mathbf{3 8 c} ; \mathrm{R}=4-\mathrm{F}$, 38d; $\mathrm{R}=3-\mathrm{CF}_{3}, \mathbf{3 8 e} ; \mathrm{R}=2-\mathrm{OCH}_{3}$<smiles>CC1(c2ccccc2)CC(=O)N(CC(=O)N2CCC(Cc3ccccc3)CC2)C1=O</smiles>

Obniska et al.

In the MES seizure test, $\mathbf{3 8 b}$, active compounds.

In the $s c$ PTZ test, 38a and $\mathbf{3 9}$ were the most active compounds.

Some compounds were also found active against the psychomotor seizure 6-Hz test, for example, 38d and 40. 


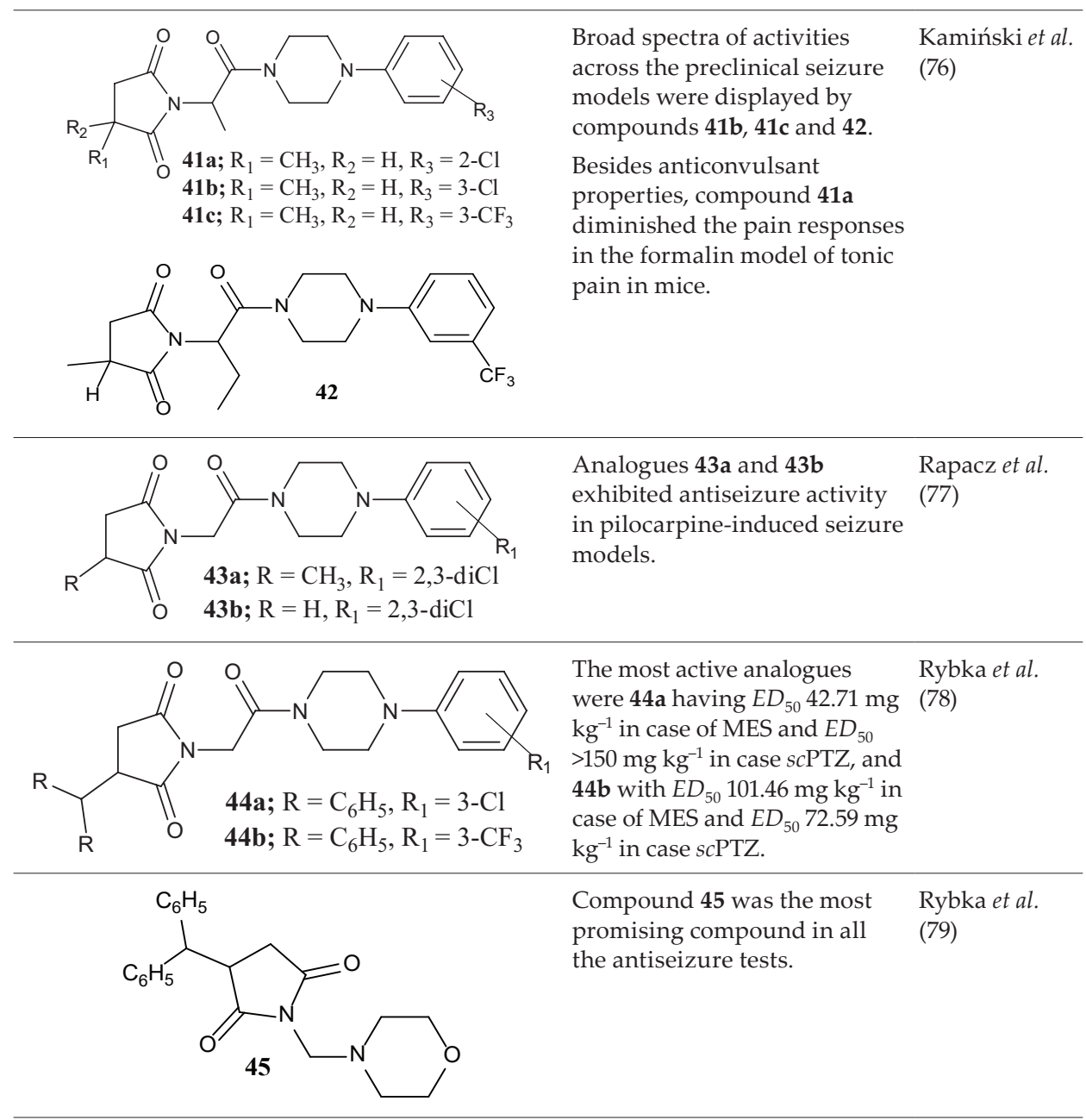

$E D_{50}$ - median effective dose, i.p. - intraperitoneally, MES - maximal electroshock seizure, scPTZ - subcutaneous pentylenetetrazole

\section{Imidazoles as anticonvulsant agents}

Imidazole and its analogues are five-membered heterocyclic structures having two nitrogen atoms separated by one carbon atom. Recent studies have revealed that imidazole analogues have attracted a great deal of attention owing to their broad range of biological activities such as analgesic (80), anti-inflammatory (81), etc. Literature survey has also shown that imidazole-heterocyclic analogues could be an important class of antiseizure agents; an existing antiseizure drug, phenytoin, contains an imidazole ring (82). Some potent and recently developed imidazole bearing anticonvulsant agents are summarized in Table V. 
Table V. Some recently developed imidazoles as anticonvulsant agents

Summary/conclusion
Compound 46 was highly active
$\begin{aligned} & \text { Cith } E D_{50} \text { and } T D_{50} \text { values of } 38.46 \\ & \mathrm{mg} \mathrm{kg}^{-1} \text { and } 123.83 \mathrm{mg} \mathrm{kg}^{-1} \text { in mice, } \\ & \text { and } 20.44 \mathrm{mg} \mathrm{kg}^{-1} \text { and } 56.36 \mathrm{mg} \mathrm{kg}^{-1} \\ & \text { in rats. }\end{aligned}$<smiles>Cc1ccc(NC(=O)N/N=C(/Cn2ccnc2)c2ccc(Cl)cc2)cc1</smiles>

Compound 48 showed the highest activity among the synthesized analogues in MES and scPTZ without any neuromotor impairment or depressant effects on CNS.

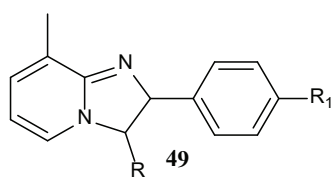

Compound 49 was highly active

Ulloora et al. (86) against electroshock (MES) and chemoshock (scPTZ) models.

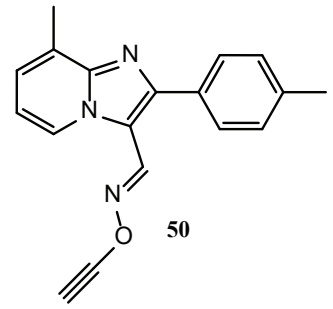

Compound $\mathbf{5 0}$ was found highly

Ulloora et al. (87) active in MES at both time intervals, i.e., 0.5 and $4 \mathrm{~h}$, suggesting a rapid onset and long duration of action. 


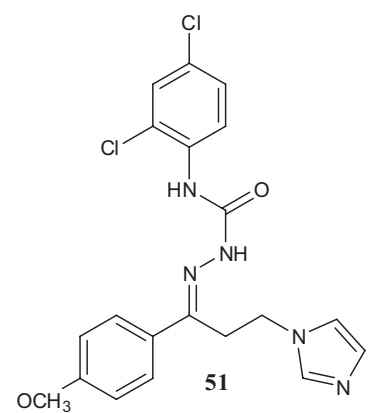

Compound 51 emerged as a highly

Attia et al. (88)

active candidate showing $100 \%$

protection at a very low dose in the

chemoshock (scPTZ) screen without

any neuromotor impairment.

CNS - central nervous system, $E D_{50}$ - median effective dose, MES - maximal electroshock seizure, scPTZ - subcutaneous pentylenetetrazole, $T D_{50}-$ median toxic dose

\section{Benzothiazoles as anticonvulsants}

Benzothiazole belongs to the family of bicyclic heterocyclic compounds having the benzene nucleus fused with a five-membered ring comprising nitrogen and sulfur atoms. Benzothiazole is an important scaffold with a wide spectrum of biological activities (89).

Work on benzothiazoles as anticonvulsant agents started recently and now we have a modest number of articles that validate benzothiazoles as potential candidates for controlling seizures (Table VI) (90-100).

\section{Functionalized amino acids (derivatives of amino acids) as anticonvulsants}

Kohn and his team (101) revealed a novel class of anticonvulsants which were analogues of amino acids, called functionalized amino acids. Functionalization of the amino and carboxyl terminal of amino acids with different substituents exhibits anticonvulsant activity (102-105).

Heterocyclic amino acid derivatives are based on a proline-like structure having a nitrogen-containing ring in which the nitrogen atom of heterocyclic moiety will serve as amino function and carboxylic group will be attached to the ring. Fig. 4 shows some heterocyclic amino acid derivatives that are used as an add-on therapy for the treatment of epilepsy.<smiles>O=C(O)C1CCCN1</smiles>

Proline<smiles>O=C(O)C1CCCNC1</smiles>

Nipecotic acid<smiles>Cc1ccsc1C(CCCN1CCCC(C(=O)O)C1)c1sccc1C</smiles>

Tiagabine

Fig. 4. Amino acid derivatives used as anticonvulsant agents. 


\section{Newly developed benzothiazoles as anticonvulsants}

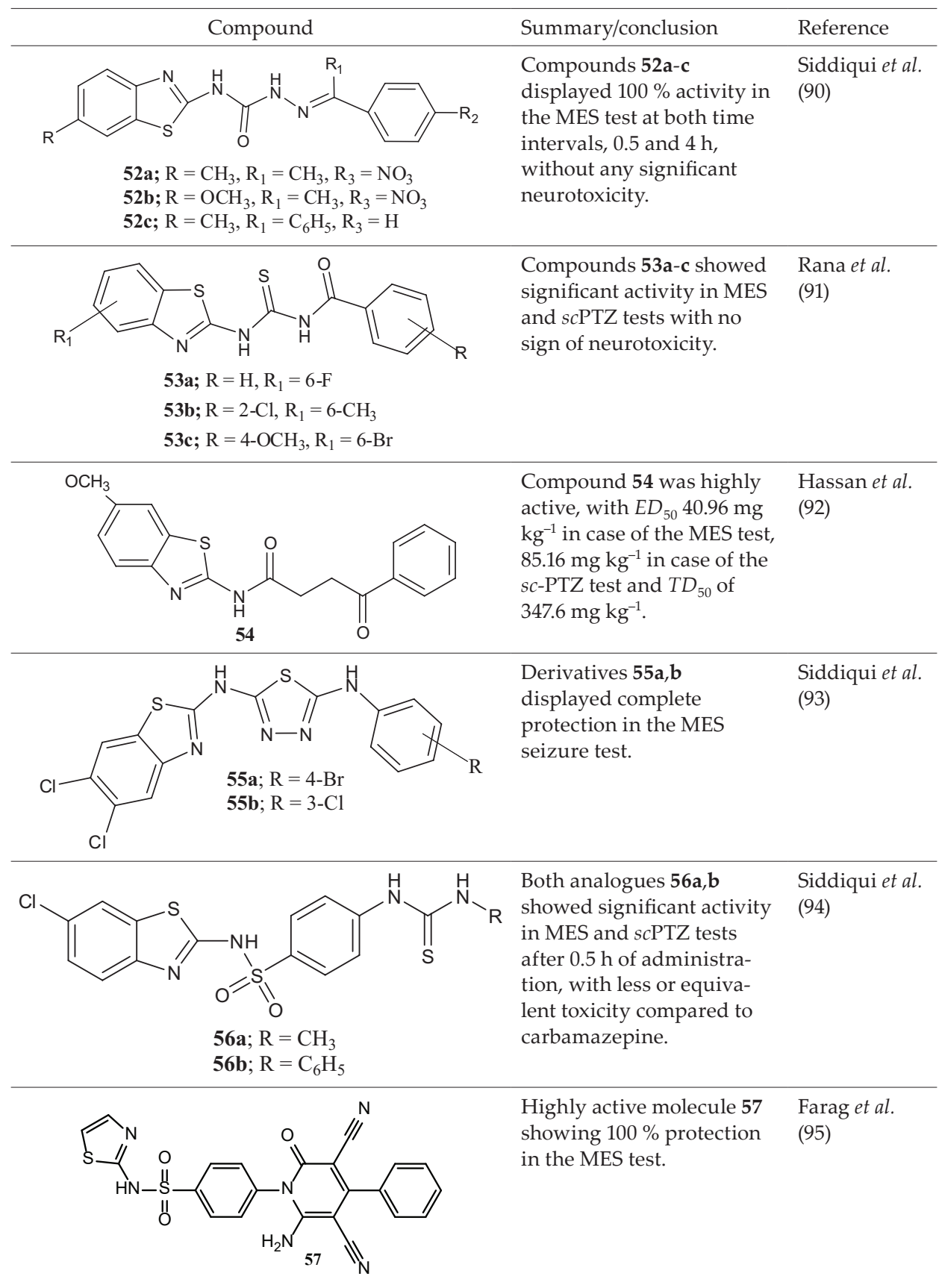




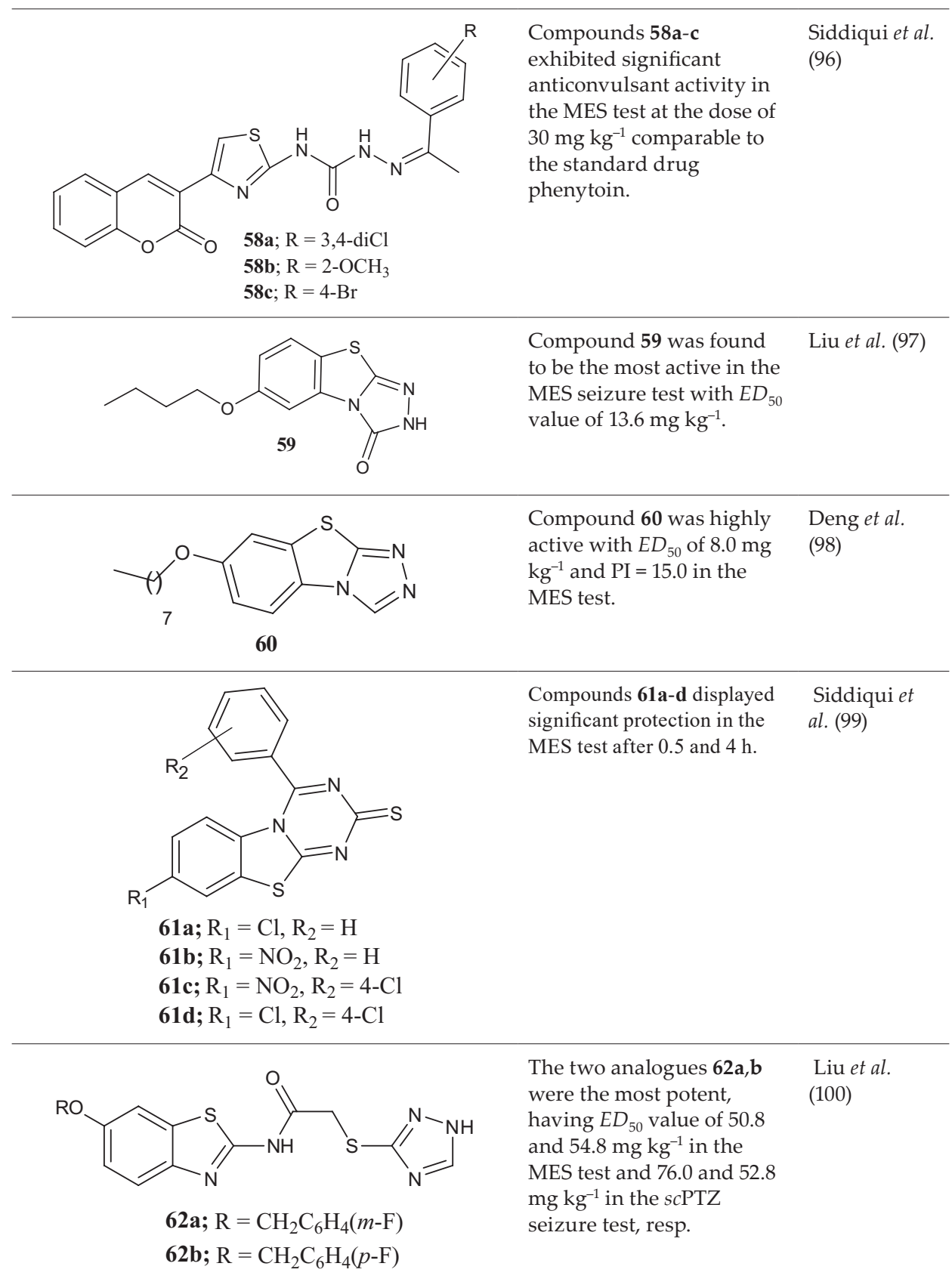

$E D_{50}$ - median effective dose, MES - maximal electroshock seizure, PI - protective index, scPTZ - subcutaneous pentylenetetrazole, $T D_{50}-$ median toxic dose 
Table VII. Recently developed functionalized amino acids as anticonvulsants

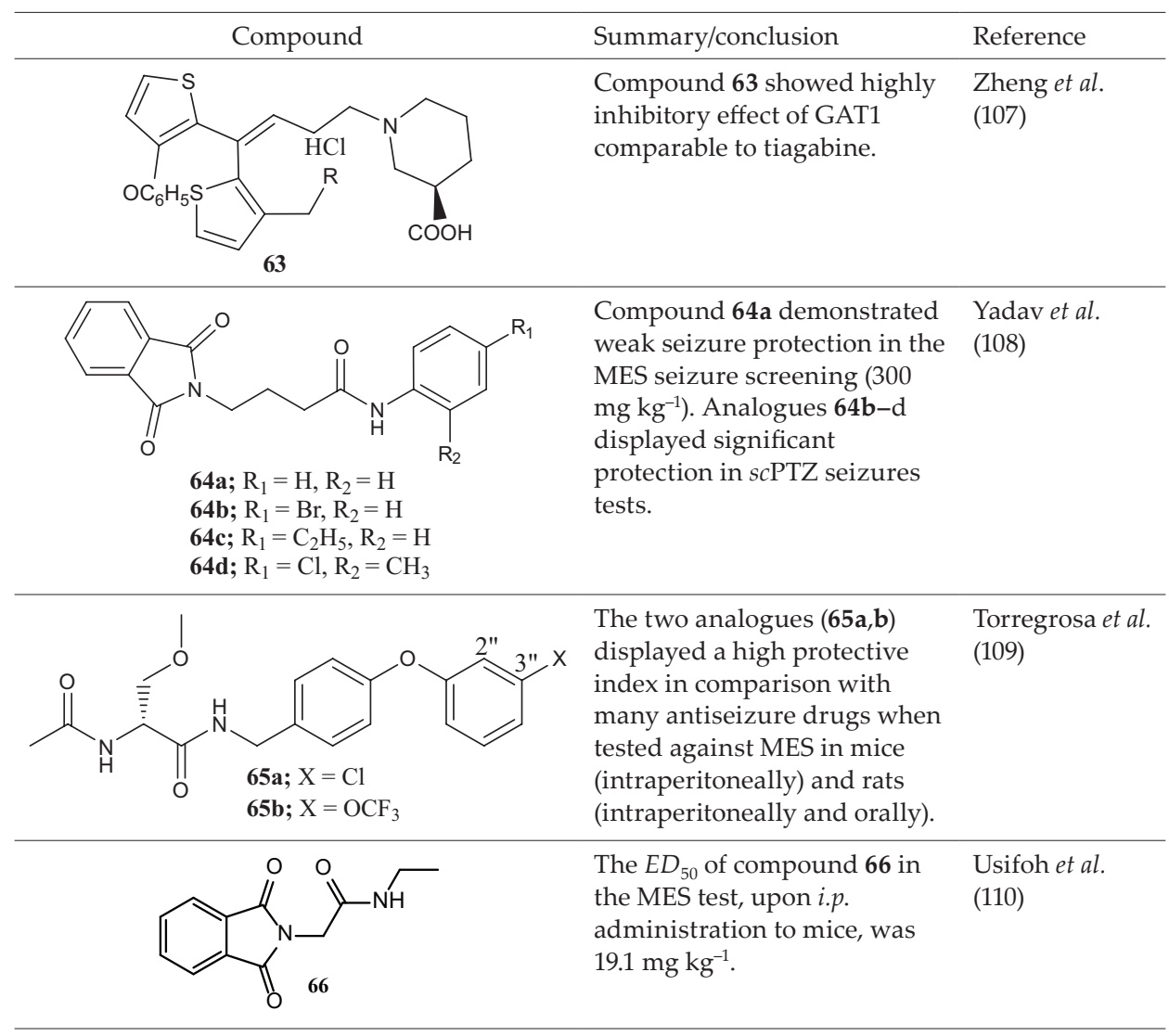

$E D_{50}$ - median effective dose, GAT1 - GABA transpoter-1, i.p. - intraperitoneally, MES - maximal electroshock seizure, MES - maximal electroshock seizure, scPTZ - subcutaneous pentylenetetrazole

Tiagabine, a heterocyclic amino acid analogue with nipecotic acid function, is used as a prescription medicine for the treatment of partial seizures (106). A fair number of newly synthesized amino acid derivatives as potential anticonvulsant agents are summarized in Table VII.

\section{CONCLUSIONS}

The present review provides an insight into new chemical entities that have shown promising antiepileptic activity and updates the knowledge of currently available AEDs.

Many of the agents shown in this review have been screened by the antiepileptic drug development program. Their antiseizure activity has been assessed through in vivo screen- 
ings, although the exact mode of action of many agents is still unidentified. Some of the newer anticonvulsant analogues are prepared via structural changes of pre-existing drugs, whereas others have been developed with the specific objective of altering targets. Such new synthetic agents generally come from different chemical groups. Some of them represent compounds containing five- or six-membered or other heterocyclic rings in their structure. However, a significant number of literature reports suggest that analogues of amino acids can act as valuable antiseizure agents. Discovery of a large number of active leads may also help in finding alternative drug candidates in the event of drug tolerance. Compounds mentioned in this review can be used in the future as potential drug candidates with more efficacy and lesser toxicity.

Abbreviations, acronyms, symbols. - AEDs - antiepileptic drugs; AMPA - $\alpha$-amino-3-hydroxy-5-methyl-4-isoxazolepropionic acid; CA - carbonic anhydrase; CHRNA2 - cholinergic receptor nicotinic alpha 2 subunit; CHRNA4 - cholinergic receptor nicotinic alpha 4 subunit; CHRNB2 - cholinergic receptor nicotinic beta 2 subunit; CNS - central nervous system; DBS - deep brain stimulation; $E D_{50}$ - median effective dose; GABA - $\gamma$-aminobutyric acid; i.p. - intraperitoneal; NMDA - N-methyl- D-aspartate; GABRG2 - gamma-aminobutyric acid type A receptor gamma 2 subunit; GAT1 - GABA transpoter-1; GEFS+ - generalized epilepsy with febrile seizures plus; MBD2 - methyl cytosine-phosphate-guanine binding domain 2; MES - maximal electroshock seizure; PI - protective index; SCN1A - sodium voltage-gated channel alpha 1 subunit; SCN2A - sodium voltage-gated channel alpha 2 subunit; $S C N 3 \mathrm{~A}$ - sodium voltage-gated channel alpha 3 subunit; SCN1B - sodium voltage-gated channel beta 1 subunit; SCN2B - sodium voltage-gated channel beta 2 subunit; scPTZ - subcutaneous pentylenetetrazole; SSA - succinate semi-aldehyde; SV2 - synaptic vesicle protein $2 ; \mathrm{TD}_{50}$ - median toxic dose

\section{REFERENCES}

1. R. Fisher, W. Boas, W. Blume, C. Elger, P. Genton, P. Lee and J. Engel, Epileptic seizures and epilepsy: definitions proposed by the international league against epilepsy (ILAE) and the international bureau for epilepsy (IBE), Epilepsia 46 (2005) 470-472; https://doi.org/10.1111/j.0013-9580.2005.66104.x

2. P. A. Dekker, Epilepsy: A Manual for Medical and Clinical Officers in Africa, WHO, Geneva 2002, pp. 133.

3. M. J. Brodie, A. T. Elder and P. Kwan, Epilepsy in later life, Lancet Neurol. 8 (2009) 1019-1030; https://doi. org/10.1016/S1474-4422(09)70240-6

4. E. Proulx, Y. Leshchenko, L. Kokarovtseva, V. Khokhotva, M. El-Beheiry, O. C. Snead and J. L. P. Velazquez, Functional contribution of specific brain areas to absence seizures: role of thalamic gapjunctional coupling, Eur. J. Neurosci. 23 (2006) 489-496; https://doi.org/10.1111/j.1460-9568.2005.04558.x

5. S. F. Berkovic, R. A. Howell, D. A. Hay and J. L. Hopper, Epilepsies in twins: Genetics of the major epilepsy syndromes, Ann. Neurol. 43 (1998) 435-445; https://doi.org/10.1002/ana.410430405

6. L. A. Corey, J. M. Pellock, M. J. Kjeldsen and K. O. Nakken, Importance of genetic factors in the occurrence of epilepsy syndrome type: A twin study, Epilepsy Res. 97 (2011) 103-111; https://doi.org/10.1016/j. eplepsyres.2011.07.018

7. M. J. Kjeldsen, L. A. Corey, M. H. Solaas, M. L. Friis, J. R. Harris, K. O. Kyvik, K. Christensen and J. M. Pellock, Genetic factors in seizures: A population-based study of 47,626 US, Norwegian and Danish twin pairs, Twin Res. Hum. Genet. 8 (2005) 138-147; https://doi.org/10.1375/1832427053738836

8. M. Li, X. Heng, R. Tao, J. Liu, L. Zhang, X. Sun, L. Wang, Q. Wu, F. Che and F. Xue, A genetic epidemiological survey of idiopathic epilepsy in the Chinese Han population, Epilepsy Res. 98 (2012) 199205; https://doi.org/10.1016/j.eplepsyres.2011.09.013 
9. R. R. Nair and S. V. Thomas, Genetic liability to epilepsy in Kerala State India, Epilepsy Res. 62 (2004) 163-170; https://doi.org/10.1016/j.eplepsyres.2004.08.007

10. R. Ottman, Genetic influences on risk for epilepsy, in Pediatric Epilepsy: Diagnosis and Therapy, Demos Medical Publishing, New York 2007.

11. H. J. Li, R. P. Wan, L. J. Tang, S. J. Liu, Q. H. Zhao, M. M. Gao, Y. H. Yi, W. P. Liao, X. F. Sun and Y. S. Long, Alteration of Scn3a expression is mediated via CpG methylation and MBD2 in mouse hippocampus during postnatal development and seizure condition, Biochim. Biophys. Acta 1849 (2015) 1-9; https://doi.org/10.1016/j.bbagrm.2014.11.004

12. K. Nagai, T. Natori, T. Nishino and F. Kodaira, Epigenetic dysregulation induces cell growth retardation in primary cultured glial cells, J. Biosci. Bioeng. 105 (2008) 470-475; https://doi.org/10.1263/ jbb.105.470

13. E. Hessen, M. I. Lossius, I. Reinvang and L. Gjerstad, Influence of major antiepileptic drugs on attention, reaction time, and speed of information processing: results from a randomized, double-blind, placebo-controlled withdrawal study of seizure-free epilepsy patients receiving monotherapy, Epilepsia 47 (2006) 2038-2045; https://doi.org/10.1111/j.1528-1167.2006.00805.x

14. V. C. Terra, R. Amorim, C. Silvado, A. J. de Oliveira, C. L. Jorge, E. Faveret, P. Ragazzo and L. De Paola, Vagus nerve stimulator in patients with epilepsy: indications and recommendations for use, Arq. Neuro-Psiquiatr. 71 (2013) 902-906; https://doi.org/10.1590/0004-282X20130116

15. P. Lisowska and B. Daly, Vagus nerve stimulation therapy (VNST) in epilepsy - implications for dental practice, Br. Dent. J. 212 (2012) 69-72; https://doi.org/10.1038/sj.bdj.2012.47

16. B. M. Uthman, Vagus nerve stimulation for seizures, Arch. Med. Res. 31 (2000) 300-303; https://doi. org/10.1016/S0188-4409(00)00060-6

17. I. S. Cooper and A. R. M. Upton, Use of chronic cerebellar stimulation for disorders of disinhibition, Lancet 311 (1978) 595-600; https://doi.org/https://doi.org/10.1016/S0140-6736(78)91038-3

18. I. S. Cooper, A. R. M. Upton and I. Amin, Reversibility of chronic neurologic deficits: Some effects of electrical stimulation of the thalamus and internal capsule in man, Appl. Neurophysiol. 43 (1980) 224258; https://doi.org/10.1159/000102263

19. K. W. Baranano and A. L. Hartman, The ketogenic diet: Uses in epilepsy and other neurologic illnesses, Curr. Treat. Options Neurol. 10 (2008) 410-419.

20. A. L. Rogovik and R. D. Goldman, Ketogenic diet for treatment of epilepsy, Can. Fam. Physician 56 (2010) 540-542.

21. M. Greener, Food for thought: the ketogenic diet for epilepsy, Prog. Neurol. Psychiatry 18 (2014) 6-9; https://doi.org/10.1002/pnp.329

22. M. Ne, L. Ngo, J. I. Sirven and M. R. Sperling, Ketogenic diet in adolescents and adults with epilepsy, Seizure 23 (2014) 439-442; https://doi.org/10.1016/j.seizure.2014.02.015

23. R. Hanaya and K. Arita, The new antiepileptic drugs: their neuropharmacology and clinical indications, Neurol. Med. Chir. (Tokyo) 56 (2016) 205-220; https://doi.org/10.2176/nmc.ra.2015-0344

24. J. A. French and D. M. Gazzola, New generation antiepileptic drugs: what do they offer in terms of improved tolerability and safety? Ther. Adv. Drug Saf. 2 (2011) 141-158; https://doi.org/10.1177/ 2042098611411127

25. G. Gatti, I. Bonomi, G. Jannuzzi and E. Perucca, The new antiepileptic drugs: Pharmacological and clinical aspects, Curr. Pharm. Design 6 (2000) 839-860; https://doi.org/10.2174/1381612003400245

26. A. Nicolson and J. P. Leach, Future prospects for the drug treatment of epilepsy, CNS Drugs 15 (2001) 955-968; https://doi.org/10.2165/00023210-200115120-00005

27. C. T. Supuran, F. Mincione, A. Scozzafava, F. Briganti, G. Mincione and M. A. Ilies, Carbonic anhydrase inhibitors - Part 52. Metal complexes of heterocyclic sulfonamides: A new class of strong topical 
intraocular pressure-lowering agents in rabbits, Eur. J. Med. Chem. 33 (1998) 247-254; https://doi. org/10.1016/S0223-5234(98)80059-7

28. M. Ilies, C. T. Supuran, A. Scozzafava, A. Casini, F. Mincione, L. Menabuoni, M. T. Caproiu, M. Maganu and M. D. Banciu, Carbonic anhydrase inhibitors. Sulfonamides incorporating furan-, thiopheneand pyrrole-carboxamido groups possess strong topical intraocular pressure lowering properties as aqueous suspensions, Bioorg. Med. Chem. 8 (2000) 2145-2155; https://doi.org/10.1016/S09680896(00)00143-7

29. A. Scozzafava, L. Menabuoni, F. Mincone, F. Briganti, G. Mincione and C. T. Supuran, Carbonic anhydrase inhibitors. Perfluoroalkyl/aryl-substituted derivatives of aromatic/heterocyclic sulfonamides as topical intraocular pressure lowering agents with prolonged duration of action, J. Med. Chem. 43 (2000) 4542-4551; https://doi.org/10.1021/jm000296j

30. A. Casini, A. Scozzafava, F. Mincione, L. Menabuoni, M. A. Ilies and C. T. Supuran, Carbonic anhydrase inhibitors: Water soluble 4-sulfamoylphenyl-thioureas as topical intraocular pressure-lowering agents with long-lasting effects, J. Med. Chem. 43 (2000) 4884-4892; https://doi.org/10.1021/jm001051+

31. B. Masereel, S. Rolin, F. Abbate, A. Scozzafava and C. T. Supuran, Carbonic anhydrase inhibitors: Anticonvulsant sulfonamides incorporating valproyl and other lipophilic moieties, J. Med. Chem. 45 (2002) 312-320; https://doi.org/10.1021/jm0109199

32. M. A. Ilies, B. Masereel, S. Rolin, A. Scozzafava, G. Câmpeanu, V. Cîmpeanu and C. T. Supuran, Carbonic anhydrase inhibitors: aromatic and heterocyclic sulfonamides incorporating adamantyl moieties with strong anticonvulsant activity, Bioorg. Med. Chem. 12 (2004) 2717-2726; https://doi. org/10.1016/j.bmc.2004.03.008

33. I. B. Linden, G. Gothoni, P. Kontro and S. S. Oja, Anticonvulsant activity of 2-phthalimidoethane sulphonamides: New derivatives of taurine, Neurochem. Int. 5 (1983) 319-324; https://doi.org/10.1016/j. bmc.2004.03.008

34. O. Akgul, F. S. Kilic, K. Erol and V. Pabuccuoglu, Synthesis and anticonvulsant activity of some Nphenyl-2-phtalimidoethanesulfonamide derivatives, Arch. Pharm. (Weinheim) 340 (2007) 656-660; https://doi.org/10.1002/ardp.200700166

35. N. Siddiqui, M. F. Arshad, S. A. Khan and W. Ahsan, Sulfonamide derivatives of thiazolidin-4-ones with anticonvulsant activity against two seizure models: synthesis and pharmacological evaluation, J. Enzyme Inhib. Med. Chem. 25 (2010) 485-491; https://doi.org/10.3109/14756360903282833

36. Y. Hu, C. Y. Li, X. M. Wang. Y. H. Yang and H. L. Zhu, 1,3,4-Thiadiazole: Synthesis, reactions, and applications in medicinal, agricultural, and materials chemistry, Chem. Rev. 114 (2014) 5572-5610; https:// doi.org/10.1021/cr400131u

37. A. K. Jain, S. Sharma, A. Vaidya, V. Ramachandran and R. K. Agrawal, 1,3,4-Thiadiazole and its derivatives: a review on recent progress in biological activities, Chem. Biol. Drug Des. 81 (2013) 557-576; https://doi.org/10.1111/cbdd.12125

38. W. Dehaen, V. A. Bakulev, E. C. Taylor and J. A. Ellman, The Chemistry of 1,2,3-thiadiazoles, in The Chemistry of Heterocyclic Compounds (Ed. E. C. Taylor), 1 ${ }^{\text {st }}$ ed., John Wiley \& Sons, New York 2004, pp. 5-240.

39. A. Gupta, P. Mishra, S. Kashaw, V. Jatav and J. P. Stables, Synthesis and anticonvulsant activity of some novel 3-arylamino/amino-4-aryl-5-imino-- 2-1,2,4-thiadiazoline, Eur. J. Med. Chem. 43 (2008) 749-754; https://doi.org/10.1016/j.ejmech.2007.05.008

40. A. Gupta, P. Mishra, S. N. Pandeya, S. K. Kashaw, V. Kashaw and J. P. Stables, Synthesis and anticonvulsant activity of some substituted 1,2,4-thiadiazoles, Eur. J. Med. Chem. 44 (2009) 1100-1105; https:// doi.org/10.1016/j.ejmech.2008.06.015

41. B. Ahamad and M. Yusuf, Synthesis of aromatic aldehyde imine derivative of 2-thiobenzyl-1,3,4-thiadiazole and evaluation of their anticonvulsant activity, Indian J. Chem. B 49 (2010) 241-246. 
42. V. Jatav, P. Mishra, S. Kashaw and J. P. Stables, CNS depressant and anticonvulsant activities of some novel 3-[5-substituted1,3,4-thiadiazole-2-yl]-2-styryl quinazoline-4(3H)-ones, Eur. J. Med. Chem. 43 (2008) 1945-1954; https://doi.org/10.1016/j.ejmech.2007.12.003

43. A. Foroumadi, V. Sheibani, A. Sakhteman, M. Rameshk, M. Abbasi, R. Farazifard, S. A. Tabatabai and A. Shafiee, Synthesis and anticonvulsant activity of novel 2-amino-5-[4-chloro-2- (2- chlorophenoxy) phenyl]-1,3,4-thiadiazole derivatives, DARU J. Pharm. Sci. 15 (2007) 89-93.

44. X. Q. Deng, Z. Q. Dong, M. X. Song, B. Shu, S. B. Wang and Z. S. Quan, Synthesis and anticonvulsant activities of some triazolothiadiazole derivatives, Arch. Pharm. (Weinheim) 345 (2012) 565-573; https:// doi.org/10.1002/ardp.201100326

45. H. Rajak, C. K. Behera, R. S. Pawar, P. K. Singour and M. D. Kharya, Synthesis and anticonvulsant evaluation of some novel 2,5-disubstituted 1,3,4-thiadiazoles: pharmacophore model studies, Acta Pol. Pharm. 67 (2010) 503-510.

46. H. Rajak, B. S. Thakur, P. Kumar, P. Parmar, P. C. Sharma, R. Veerasamy and M. D. Kharya, Synthesis and antiepileptic activity of some novel semicarbazones containing 1,3,4-thiadiazole and quinazoline ring, Acta Pol. Pharm. 69 (2012) 253-261.

47. N. Siddiqui, A. Rana, S. A. Khan, S. E. Haque, M. F. Arshad, S. Ahmed and W. Ahsan, Synthesis and preliminary screening of benzothiazol-2-yl-thiadiazole derivatives for anticonvulsant activity, Acta Pharm. 59 (2009) 441-451; https://doi.org/10.2478/v10007-009-0031-x

48. M. S. Yar and M. W. Akhter, Synthesis and anticonvulsant activity of substituted oxadiazole and thiadiazole derivatives, Acta Pol. Pharm. 66 (2009) 393-397.

49. K. P. Harish, K. N. Mohana and L. Mallesha, Synthesis of pyrazine substituted 1,3,4-thiadiazole derivatives and their anticonvulsant activity, Org. Chem. Int. 2013 (2013) Article ID 631723 (8 pages); https://doi.org/10.1155/2013/631723

50. A. H. Al Rohaimi, Neuropharmacological and toxicity study of newly prepared N-[5-(3-chloro4-fluorophenyl)-1,3,4-thiadiazol-2-yl]- 2-substituted acetamides, Acta Pol. Pharm. 72 (2015) 1315-1320.

51. J. R. Dimmock, S. C. Vashistha and J. P. Stable, Anticonvulsant properties of various acetylhydrazones, oxymoylhydrazones, and semicarbazones derived from aromatic and unsaturated carbonyl compounds, Eur. J. Med. Chem. 35 (2000) 241-248; https://doi.org/10.1016/S0223-5234(00)00123-9

52. J. R. Dimmock, S. C. Vashistha and J. P. Stable, Ureylene anticonvulsants and related compounds, Pharmazie 55 (2000) 490-494.

53. S. N. Pandeya, H. Manjula and J. P. Stables, Design of semicarbazones and their bio-isosteric analogues as potential anticonvulsants, Pharmazie 56 (2001) 121-124.

54. S. N. Pandeya, I. Ponnilavarasan, A. Pandey, R. Lakhan and J. P. Stables, Evaluation of p-nitrophenyl substituted semicarbazones for anticonvulsant properties, Pharmazie 54 (1999) 923-925.

55. J. R. Dimmock, R. N. Puthucode, J. Tuchek, J. B. Baker, C. N. Hinko, C. L. Steinmiller and J. P. Stable, Anticonvulsant activity of 4-(4'-fluorophenoxy)benzaldehyde semicabazone, Drug. Dev. Res. 46 (1999) 112-125; https://doi.org/10.1002/(SICI)1098-2299(199902)46:2<112::AID-DDR4>3.0.CO;2-N

56. O. Alam, P. Mallick, S. P. Verma, S. J. Gilani, S. A. Khan, N. Siddiqui and W. Ahsan, Synthesis, anticonvulsant and toxicity screening of newer pyrimidine semicarbazone derivatives, Eur. J. Med. Chem. 45 (2010) 2467-2472; https://doi.org/10.1016/j.ejmech.2010.02.031

57. P. Yogeeswari, D. Sriram, S. Mehta, D. Nigam, M. M. Kumar, S. Murugesan and J. P. Stables, Anticonvulsant and neurotoxicity evaluation of some 6-substituted benzothiazolyl-2-thiosemicarbazones, $I$. L. Farmaco 60 (2005) 1-5; https://doi.org/10.1016/j.farmac.2004.09.001

58. P. Yogeeswari, D. Sriram, V. Saraswat, J. V. Ragavendran, M. M. Kumar, S. Murugesan, R. Thirumurugan and J. P. Stables, Synthesis and anticonvulsant and neurotoxicity evaluation of N4-phthalimido phenyl (thio) semicarbazides, Eur. J. Pharm. Sci. 20 (2003) 341-346; https://doi.org/10.1016/j. ejps.2003.08.002 
59. U. Çalış, E. Septioğlu and M. D. Aytemir, Synthesis and anticonvulsant evaluation of some novel (thio) semicarbazone derivatives of arylalkylimidazole, Arzneimittelforschung 61 (2011) 327-334; https:/doi. org/10.1055/s-0031-1296206

60. F. Azam, I. A. Alkskas, S. L. Khokra and O. Prakash, Synthesis of some novel N4-(naphtha[1,2-d]thiazol-2-yl)semicarbazone as potential anticonvulsants, Eur. J. Med. Chem. 44 (2009) 203-209; https://doi. org/10.1016/j.ejmech.2008.02.007

61. E. D. Ilieva, N. I. Petkova and R. D. Nikolova, A new and efficient method for the synthesis of 3,4-disubstituted pyrrolidine-2,5-diones, Molecules 17 (2012) 4936-4949; https://doi.org/10.3390/molecules17054936

62. J. Obniska and K. Kamiński, Synthesis and anticonvulsant properties of new $N$-phenylamino derivatives of 2-azaspiro[4.4]nonane, 2-azaspiro[4.5]decane-1,3-dione and 3 cyclohexyl-pyrrolidine-2,5-dione. Part IV, Acta Pol. Pharm. 63 (2006) 101-108.

63. J. Obniska and K. Kamiński, Lipophilicity characterization of new N-phenylamino-azaspiranes as potential anticonvulsant agents, Biomed. Chromatogr. 20 (2006) 1185-1191; https://doi.org/10.1002/ bmc. 682

64. J. Obniska, R. Lesyk, D. Atamanyuk and K. Kamiński, Synthesis and anticonvulsant activity of a series of N-substituted bicyclo[2,2,1] hept-5-ene-2,3-dicarboximides, Acta Pol. Pharm. 62 (2005) 213-219.

65. J. Obniska, S. Jurczyk, A. Zejc, K. Kamiński, E. Tatarczynska and K. Stachowicz, Anticonvulsant properties of $N$-(4-methylpiperazin-1-yl)- and N-[3-(4-methyl-piperazin-1-yl)propyl] derivatives of 3-aryl and 3-spirocycloalkyl-pyrrolidine-2,5-dione, Pharmacol. Rep. 57 (2005) 170-175.

66. K. Kamiński and J. Obniska, Design, synthesis, and anticonvulsant activity of N-phenylamino derivatives of 3,3-dialkyl-pyrrolidine-2,5-diones and hexahydro-isoindole-1,3-diones, Bioorg. Med. Chem. 16 (2008) 4921-4931; https://doi.org/10.1016/j.bmc.2008.03.037

67. J. Obniska, K. Kamiński, D. Skrzynska and J. Pichor, Synthesis and anticonvulsant activity of new N-[(4-arylpiperazin-1-yl)- alkyl] derivatives of 3-phenyl-pyrrolidine-2,5-dione, Eur. J. Med. Chem. 44 (2009) 2224-2233; https://doi.org/10.1016/j.ejmech.2008.05.020

68. J. Obniska, M. Kopytko, A. Zagórska, I. Chlebek and K. Kamiński, Synthesis and anticonvulsant properties of new Mannich bases derived from 3-aryl-pyrrolidine-2,5-diones. Part 1, Arch. Pharm. (Weinheim) 343 (2010) 333-341; https://doi.org/10.1002/ardp.200900250

69. K. Kamiński, S. Rzepka and J. Obniska, Synthesis and anticonvulsant activity of new 1-[2-oxo-2-(4phenylpiperazin-1-yl)ethyl]pyrrolidine-2,5-diones, Bioorg. Med. Chem. Lett. 21 (2011) 5800-803; https:// doi.org/10.1016/j.bmcl.2011.07.118

70. J. Obniska, I. Chlebek and K. Kamiński, Synthesis and anticonvulsant properties of new Mannich bases derived from 3,3-disubstituted pyrrolidine-2,5-diones, Part IV, Arch. Pharm. (Weinheim) 345 (2012) 713-722; https://doi.org/10.1002/ardp.201200092

71. K. Kamiński, J. Obniska, I. Chlebek, B. Wiklik and S. Rzepka, Design, synthesis and anticonvulsant properties of new N-Mannich bases derived from 3-phenylpyrrolidine-2,5-diones, Bioorg. Med. Chem. Lett. 21 (2013) 6821-6830; https://doi.org/10.1016/j.bmc.2013.07.029

72. J. Obniska, I. Chlebek, K. Kamiński and J. Karolak-Wojciechowska, Synthesis and anticonvulsant properties of new N-Mannich bases derived from 3, 3-diphenyl- and 3-ethyl-3-methyl-pyrrolidine-2,5diones, Part III, Arch. Pharm. (Weinheim) 346 (2013) 71-82; https://doi.org/10.1002/ardp.201200265

73. K. Kamiński, B. Wiklik and J. Obniska, Synthesis, anticonvulsant properties, and SAR analysis of differently substituted pyrrolidine-2,5-diones and piperidine-2,6-diones, Arch. Pharm. (Weinheim) 347 (2014) 840-852; https://doi.org/10.1002/ardp.201400179

74. S. Rybka, J. Obniska, A. Rapacz, B. Filipek and K. Kamiński, Synthesis, physicochemical, and anticonvulsant properties of new N-Mannich bases derived from pyrrolidine-2,5-dione and its 3-methyl analog, Arch. Pharm. (Weinheim) 347 (2014) 768-776; https://doi.org/10.1002/ardp.201400152 
75. J. Obniska, A. Rapacz, S. Rybka, B. Powroznik, E. Pekala, B. Filipek, P. Zmudzki and K. Kamiński, Design, synthesis and biological activity of new amides derived from 3-methyl-3-phenyl-2, 5-dioxopyrrolidin-1-yl-acetic acid, Eur. J. Med. Chem. 102 (2015) 14-25; https://doi.org/10.1016/j.ejmech.2015.07.017

76. K. Kamiński, M. Zagaja, A. Rapacz, J. J. Tuszczki, M. Andres-Mach, M. Abram and J. Obniska, New hybrid molecules with anticonvulsant and antinociceptive activity derived from 3-methyl- or 3,3-dimethyl-1-[1-oxo-1-(4-phenylpiperazin-1-yl) propan-2-yl]pyrrolidine-2,5-diones, Bioorg. Med. Chem. 24 (2016) 606-618; https://doi.org/10.1016/j.bmc.2015.12.027

77. A. Rapacz, S. Rybka, J. Obniska, K. Sałat, B. Powroźnik, E. Pękala and B. Filipek, Evaluation of anticonvulsant and antinociceptive properties of new N-Mannich bases derived from pyrrolidine-2,5-dione and 3-methylpyrrolidine-2,5-dione, Naunyn-Schmiedeberg Arch. Pharmacol. 389 (2016) 339-348; https:// doi.org/10.1007/s00210-015-1194-2

78. S. Rybka, J. Obniska, A. Rapacz, B. Filipek and P. Zmudzki, Synthesis and anticonvulsant activity of new N-Mannich bases derived from benzhydryl- and isopropyl-pyrrolidine-2,5-dione, J. Enzyme Inhib. Med. Chem. 31 (2016) 1038-1047; https://doi.org/10.3109/14756366.2015.1088842

79. S. Rybka, J. Obniska, A. Rapacz, B. Filipek and P. Zmudzki, Synthesis and evaluation of anticonvulsant properties of new N-Mannich bases derived from pyrrolidine-2,5-dione and its 3- methyl-, 3-isopropyl, and 3-benzhydryl analogs, Bioorg. Med. Chem. Lett. 27 (2017) 1412-1415; https://doi.org/10.1016/j. bmcl.2017.02.002

80. F. Schiaffella, A. Macchiarulo, L. Milanese, A. Vecchiarelli and R. Fringuelli, Novel ketoconazole analogues based on the replacement of 2,4-dichlorophenyl group with 1,4-benzothiazine moiety: Design, synthesis, and microbiological evaluation, Bioorg. Med. Chem. 14 (2006) 5196-5203; https://doi. org/10.1016/j.bmc.2006.04.004

81. L. Navidpour, H. Shadnia, H. Shafaroodi, M. Amini, A. R. Dehpour and A. Shafiee, Design, synthesis, and biological evaluation of substituted 2-alkylthio-1,5-diarylimidazoles as selective COX-2 inhibitors, Bioorg. Med. Chem. 15 (2007) 1976-1982; https://doi.org/10.1016/j.bmc.2006.12.041

82. J. C. Thenmozhiyal, P. T. Wong and W. K. Chui, Anticonvulsant activity of phenylmethyl-enehydantoins: A structure-activity relationship study, J. Med. Chem. 47 (2004) 1527-1535; https://doi.org/10.1021/ jm030450c

83. A. Karakurt, M. Ozalp, S. Isik, J. P. Stables and S. Dalkara, Synthesis, anticonvulsant and antimicrobial activities of some new 2-acetylnaphthalene derivatives, Bioorg. Med. Chem. 18 (2010) 2902-2911; https://doi.org/10.1016/j.bmc.2010.03.010

84. A. Husain, N. Siddiqui, M. Sarafroz, Y. Khatoon, M. Rasid and N. Ahmad, Synthesis, anticonvulsant and neurotoxicity screening of some novel 1,2,4-trisubstituted-1H-imidazole derivatives, Acta Pol. Pharm. 68 (2011) 657-663.

85. M. Amir, I. Ali and M. Z. Hassan, Imidazole incorporated semicarbazone derivatives as a new class of anticonvulsants: Design, synthesis and in vivo screening, Med. Chem. 9 (2013) 571-580; https://doi. org/10.2174/1573406411309040011

86. S. Ulloora, R. Shabaraya, S. Aamir and A. V. Adhikari, New imidazo[1,2-a]pyridines carrying active pharmacophores: Synthesis and anticonvulsant studies, Bioorg. Med. Chem. Lett. 23 (2013) 1502-1506; https://doi.org/10.1016/j.bmcl.2012.12.035

87. S. Ulloora, R. Shabaraya and A. V. Adhikari, Facile synthesis of new imidazo[1,2-a] pyridines carrying 1,2,3-triazoles via click chemistry and their antiepileptic studies, Bioorg. Med. Chem. Lett. 23 (2013) 3368-3372; https://doi.org/10.1016/j.bmcl.2013.03.086

88. M. I. Attia, M. N. Aboul-Enein, A. A. El-Azzouny, Y. A. Maklad and H. A. Ghabbour, Anticonvulsant potential of certain new (2E)-2-[1-aryl-3-(1H-imidazol-1-yl)propylidene]- $N$-(aryl/H) hydrazinecarboxamides, Sci. World J. 2014 (2014) Article ID 357403 (9 pages); https://doi.org/10.1155/2014/357403

89. R. K. Gill, R. K. Rawal and J. Bariwal, Recent advances in the chemistry and biology of benzothiazoles, Arch. Pharm. (Weinheim) 348 (2015) 155-178; https://doi.org/10.1002/ardp.201400340 
90. N. Siddiqui, A. Rana, S. A. Khan, M. A. Bhat and S. E. Haque, Synthesis of benzothiazole semicarbazones as novel anticonvulsants - the role of hydrophobic domain, Bioorg. Med. Chem. Lett. 17 (2007) 4178-4182; https://doi.org/10.1016/j.bmcl.2007.05.048

91. A. Rana, N. Siddiqui, S. A. Khan, S. E. Haque and M. A. Bhat, N-\{[(6-substituted-1,3-benzothiazole2-yl)amino]carbonothioyl\}-2/4-substituted benzamides: Synthesis and pharmacological evaluation, Eur. J. Med. Chem. 43 (2008) 1114-1122; https://doi.org/10.1016/j.ejmech.2007.07.008

92. M. Z. Hassan, S. A. Khan and M. Amir, Design, synthesis and evaluation of N-(substituted benzothiazol-2-yl) amides as anticonvulsant and neuroprotective, Eur. J. Med. Chem. 58 (2012) 206-213; https://doi.org/10.1016/j.ejmech.2012.10.002

93. N. Siddiqui, A. Rana, S. A. Khan, S. E. Haque, M. F. Arshad, S. Ahmed and W. Ahsan, Synthesis and preliminary screening of benzothiazol-2-yl thiadiazole derivatives for anticonvulsant activity, Acta Pharm. 59 (2009) 441-451; https://doi.org/10.2478/v10007-009-0031-x

94. N. Siddiqui, S. N. Pandeya, S. A. Khan, J. Stables, A. Rana, M. Alam, M. F. Arshad and M. A. Bhat, Synthesis and anticonvulsant activity of sulfonamide derivatives-hydrophobic domain, Bioorg. Med. Chem. Lett. 17 (2007) 255-259; https://doi.org/10.1016/j.bmcl.2006.09.053

95. A. A. Farag, S. N. Abd-Alrahman, G. F. Ahmed, R. M. Ammar, Y. A. Ammar and S. Y. Abbas, Synthesis of some azoles incorporating a sulfonamide moiety as anticonvulsant agents, Arch. Pharm. (Weinheim) 345 (2012) 703-712; https://doi.org/10.1002/ardp.201200014

96. N. Siddiqui, M. F. Arshad and S. A. Khan, Synthesis of some new coumarin incorporated thiazolyl semicarbazones as anticonvulsants, Acta Pol. Pharm. 66 (2009) 161-167.

97.D. C. Liu, X. Q. Deng, S. B. Wang and Z. S. Quan, Synthesis and anticonvulsant activity evaluation of 7-alkoxy[1,2,4]triazolo[3,4-b]benzothiazol-3(2H)-ones, Arch. Pharm. (Weinheim) 347 (2014) 268-275; https://doi.org/10.1002/ardp.201300277

98. X. Q. Deng, M. X. Song, C. X. Wei, F. N. Li and Z. S. Quan, Synthesis and anticonvulsant activity of 7-alkoxy-triazolo-[3,4-b]benzo[d]thiazoles, Med. Chem. 6 (2010) 313-320; https://doi. org/10.2174/157340610793358855

99. N. Siddiqui, A. Rana, S. A. Khan, S. E. Haque, M. S. Alam, W. Ahsan and S. Ahmed, Synthesis of 8-substituted-4-(2/4-substituted phenyl)-2H-[1,3,5]triazino[2,1- $b][1,3]$ benzothiazole-2-thiones and their anticonvulsant, anti-nociceptive, and toxicity evaluation in mice, J. Enzyme Inhib. Med. Chem. 24 (2009) 1344-1350; https://doi.org/10.3109/14756360902888176

100. D. Liu, H. Zhang, C. Jin and Z. Quan, Synthesis and biological evaluation of novel benzothiazole derivatives as potential anticonvulsant agents, Molecules 21 (2016) Article ID 164 (13 pages); https:/ doi.org/10.3390/molecules21030164

101. J. D. Conley and H. Kohn, Functionalized DL-amino acid derivatives. Potent new agents for the treatment of epilepsy, J. Med. Chem. 30 (1987) 567-574; https://doi.org/10.1021/jm00386a021

102. H. Kohn, J. D. Conley and J. D. Leander, Marked stereospecificity in a new class of anticonvulsants, Brain Res. 457 (1988) 371-375; https://doi.org/10.1016/0006-8993(88)90709-3

103. H. Kohn, K. N. Sawhney, P. LeGall, J. D. Conley, D. W. Robertson and J. D. Leander, Preparation and anticonvulsant activity of a series of functionalized $\alpha$-aromatic and $\alpha$-heteroaromatic amino acids, J. Med. Chem. 33 (1990) 919-926; https://doi.org/10.1021/jm00165a006

104. H. Kohn, K. N. Sawhney, P. LeGall, D. W. Robertson and J. D. Leander, Preparation and anticonvulsant activity of a series of functionalized $\alpha$-heteroatom-substituted amino acids, J. Med. Chem. 34 (1991) 2444-2452; https://doi.org/10.1021/jm00112a020

105. H. Kohn, K. N. Sawhney, P. Bardel, D. W. Robertson and J. D. Leander, Synthesis and anticonvulsant activities of $\alpha$-heterocyclic $\alpha$-acetamido-N-benzylacetamide derivatives, J. Med. Chem. 36 (1993) 3350-3360; https://doi.org/10.1021/jm00074a016

106. K. E. Andersen, C. Braestrup, F. C. Groenwald, A. S. Joergensen, E. B. Nielsen, U. Sonnewald, P. O. Soerensen, P. D. Suzdak and L. J. S. Knutsen, The synthesis of novel GABA uptake inhibitors. 1. 
Elucidation of the structure-activity studies leading to the choice of (R)-1-[4,4-bis(3-methyl-2-thienyl)3-butenyl]-3-piperidinecarboxylic acid (Tiagabine) as an anticonvulsant drug candidate, J. Med. Chem. 36 (1993) 1716-1725; https://doi.org/10.1021/jm00064a005

107. J. Zheng, R. Wen, X. Luo, G. Lin, J. Zhang, L. Xu, L. Guo and H. Jiang, Design, synthesis, and biological evaluation of the $\mathrm{N}$-diarylalkenyl-piperidinecarboxylic acid derivatives as GABA uptake inhibitors (I), Bioorg. Med. Chem. Lett. 16 (2006) 225-227; https://doi.org/10.1016/j.bmcl.2005.09.004

108. N. Yadav, M. Malhotra, V. Monga, S. Sharma, J. Jain, Abdul Samad and A. Deep, Synthesis, characterization, and pharmacological evaluation of new GABA analogs as potent anticonvulsant agents, Med. Chem. Res. 21 (2012) 2208-2216; https://doi.org/10.1007/s00044-011-9743-9

109. R. Torregrosa, X. F. Yang, E. T. Dustrude, T. R. Cummins, R. Khanna and H. Kohn, Chimeric derivatives of functionalized amino acids and $\alpha$-aminoamides: Compounds with anticonvulsant activity in seizure models and inhibitory actions on central, peripheral, and cardiac isoforms of voltagegated sodium channels, Bioorg. Med. Chem. 23 (2015) 3655-3666; https://doi.org/10.1016/j. bmc.2015.04.014

110. C. O. Usifoh, D. M. Lambert, J. Wouters and G. K. E. Scriba, Synthesis and anticonvulsant activity of N,N-phthaloyl derivatives of central nervous system inhibitory amino acids, Arch. Pharm. (Weinheim) 334 (2001) 323-331; https://doi.org/10.1002/1521-4184(200110)334:10<323::AIDARDP323>3.0.CO;2-O 